Published in final edited form as:

Annu Rev Sociol. 2015 August 1; 41: 331-357. doi:10.1146/annurev-soc-071312-145659.

\title{
STEM Education
}

\author{
Yu Xie, \\ Department of Sociology, University of Michigan, Ann Arbor, MI 48109 \\ Michael Fang, and \\ Department of Sociology, University of Michigan, Ann Arbor, MI 48109

\section{Kimberlee Shauman} \\ Department of Sociology, University of California, Davis, CA 95616 \\ Yu Xie: yuxie@umich.edu; Michael Fang: mikefang@umich.edu; Kimberlee Shauman: kashauman@ucdavis.edu
}

\section{Abstract}

Improving science, technology, engineering, and mathematics (STEM) education, especially for traditionally disadvantaged groups, is widely recognized as pivotal to the U.S.'s long-term economic growth and security. In this article, we review and discuss current research on STEM education in the U.S., drawing on recent research in sociology and related fields. The reviewed literature shows that different social factors affect the two major components of STEM education attainment: (1) attainment of education in general, and (2) attainment of STEM education relative to non-STEM education conditional on educational attainment. Cognitive and social psychological characteristics matter for both major components, as do structural influences at the neighborhood, school, and broader cultural levels. However, while commonly used measures of socioeconomic status (SES) predict the attainment of general education, social psychological factors are more important influences on participation and achievement in STEM versus non-STEM education. Domestically, disparities by family SES, race, and gender persist in STEM education. Internationally, American students lag behind those in some countries with less economic resources. Explanations for group disparities within the U.S. and the mediocre international ranking of US student performance require more research, a task that is best accomplished through interdisciplinary approaches.

\section{Introduction}

The crucial role of science in a modern society is commonly acknowledged (Pavitt 1996; Xie \& Killewald 2012). Its central role in promoting technological innovation and sustained economic growth is not contested. Conversely, scientific progress depends on the strong financial and non-financial support of society as a whole. Social studies of science research (e.g., Ben-David 1971; Price 1986) devoted to elucidating the interplay between science and societal conditions point out that it is no accident that the United States has led the world both economically and in science, as America's economic strength has been closely linked to its advances in science and technology (NAS et al. 2007; Goldin \& Katz 2008; Xie \& Killewald 2012). Given this relationship, concern has recently resurfaced that the U.S. may 
be losing its lead in science, and therefore its economic competitive edge in an ever more globalized world (NAS et al. 2007).

While concern about the state of American science has a number of origins (Xie \& Killewald 2012), a primary cause of the pessimism is the widely held perception that science, technology, engineering, and mathematics (STEM) education in the U.S. is woefully inadequate, in both quantity and quality, and unequally available across social groups. In this article, we review and discuss current research on STEM education in the U.S., drawing on recent research in sociology and related fields.

\section{Defining STEM Education}

The acronym "STEM" is commonly used to reference a set of educational and occupational fields or domains that are related to "science," but there is inconsistency in the definition of this set and debate about whether the four fields deserve special attention as a collective entity (Gonzalez \& Kuenzi 2012). In particular, what is considered "STEM education" varies enormously by education level (Breiner et al. 2012), and this variance will be reflected in our review. At the foundational K-6 level, STEM education is synonymous with the math and science curriculum that is required for all students, so research on "STEM education" at the elementary school level focuses on participation and performance in science and math in general. STEM education is defined more specifically as the curriculum becomes increasingly specialized at progressive levels of education. For example, in grades 8-12 multiple tracks through the required math and science curriculum become available to students, as do elective courses in the social sciences (e.g., psychology), computer science, and applied topics in engineering and technology (NGSS 2015). Undergraduate and graduate education is, of course, designed around sequences of courses in specific fields that can be defined as STEM or non-STEM, but the educational experiences and outcomes vary so significantly across specific fields that researchers need to differentiate among the specific fields considered STEM (Xie \& Shauman 2003; Xie \& Killewald 2012).

There are two general approaches to defining STEM education. The first is to include education in any field defined as "STEM." This approach lumps together many disparate disciplines based on the assumption of their shared importance for promoting technological innovation, competitiveness and long-term national prosperity and security (NAS et al. 2007). It does not address the question of what constitutes a STEM field. For example, while social science is considered STEM by the National Science Foundation (NSF), it is excluded from the definition used by U.S. Immigration and Customs Enforcement for deciding special visas intended for foreign professional workers in STEM fields (Gonzalez \& Kuenzi 2012). The second approach is to emphasize logical and conceptual connections across different STEM fields so as to treat STEM education as a whole (Honey, Pearson \& Schweingruber 2014). This definition calls for curriculum and pedagogical coherence across different STEM fields. The new Next Generation Science Standards (NGSS) now being pushed for K-12 education nationwide (NGSS 2015) reflects this perspective.

One way to overcome the confusion of the definition of STEM education is to be specific in empirical studies. This is an approach taken in many sociological studies. That is, a study 
may be concerned with academic achievement or degree attainment in a specific STEM field, e.g., mathematics. Studies that focus further along the education ladder require researchers to be more specific about fields of study. In precollege years, a researcher is typically concerned with achievement in a broadly-defined subject, such as mathematics, and commonly uses measures such as standardized test scores or course grades. At college and graduate level, a researcher is typically concerned with participation in specific majors, achievement in specific courses, and attainment of degrees in specific fields that are considered part of STEM (Xie \& Shauman 2003; Xie \& Killewald 2012). In our review of the literature, we follow this practice of being specific whenever possible.

\section{The Significance of STEM Education}

Sociological research on STEM education takes place at the border between the sociologies of science and education. The sociology of science focuses on science as an important, somewhat unique social institution. In contrast, the sociology of education studies the acquisition of both general knowledge and educational credentials, as outcomes of social, familial, and institutional influences.

Science is a high-status occupation that rewards its incumbents with relatively high personal income and social prestige (Xie \& Killewald 2012; Rothwell 2013). In addition, as Merton (1942) hypothesized, science has long subscribed to a norm that is unique among high-status occupations: universalism. This means that universalistic (or meritocratic) criteria, rather than functionally irrelevant factors, such as gender, race, national origin, or religious affiliation, are ideally used to evaluate a scientist's performance. This implies that STEM education may be more universalistic than non-STEM education, in the sense that a student's achievement may be evaluated more objectively in a STEM subject than in a nonSTEM subject. If so, then STEM education can be viewed as a channel for individual social mobility, allowing socially disadvantaged persons to succeed through objectively measured criteria that are accepted by STEM educators and scientists (Xie 1989; Xie \& Killewald 2012). Indeed, this explanation has been proposed to account for the overrepresentation of Asian Americans in science and engineering since World War II (Xie \& Goyette 2003).

STEM education, however, is embedded in the general education system and its dynamics. A vast literature in economics treats education as a form of human capital that yields substantial economic returns (Mincer 1974; Card 1999), which have increased significantly in recent decades, especially for the highly educated (Autor et al. 2008). STEM education in particular carries a premium in the overall labor market (Rothwell 2013), although the earnings of basic scientists have stagnated in recent decades (Xie \& Killewald 2012). Yet a vast literature in sociology on education stratification affirms that educational attainment is highly dependent on social characteristics, including but not limited to family socioeconomic background (Blau \& Duncan 1967; Sewell et al. 1969), race and ethnicity (Fischer et al. 1996), family structure (McLanahan \& Sandefur 1994), sibship size (Blake 1981), schools (Raudenbush \& Bryk 1986), and neighborhood (Harding 2003). 


\section{Decomposition of STEM Education}

To understand STEM education, therefore, we need to recognize that it is both influenced by the many social forces that shape general educational outcomes in American society, and subject to the distinct characteristics of and influences on science as a separate institution. We therefore organize this review around these two major components of STEM education attainment: (1) attainment of education in general, and (2) attainment of STEM education relative to non-STEM education conditional on educational attainment. This decomposition does not reflect real social processes, as students, parents, and teachers in reality do not necessarily separate STEM from general education. Yet this decomposition is analytically useful for two reasons: it reflects how past research has been organized; and research shows that the social processes underlying attainment of general and STEM education are somewhat distinct (Xie \& Shauman 2003; Xie \& Killewald 2012), as will be discussed below.

Science always requires education, but education does not have to be scientific. Over the last century, education, especially postsecondary education, has become an increasingly important determinant of life chances and lifestyles in America (Fischer \& Hout 2006). Large literatures in economics and sociology attempt to explain why individuals attain education. Economics sees educational attainment as a rational economic investment that is undertaken because it yields economic returns, i.e. higher earnings (Becker 1964; Willis \& Rosen 1979). Sociology treats education as a mechanism by which families transmit social advantages or disadvantages to the next generation (Blau \& Duncan 1967; Sewell et al. 1969; Raftery \& Hout 1993) and considers how the cultural norms inherent in social class background affect educational experiences and attainment (Boudon 1974; Bowles \& Gintis 1976; Bourdieu 1977; Brand \& Xie 2010).

STEM education is special because it is required for science or engineering employment. While it is possible, indeed common, for someone with STEM education to pursue a career outside of science and engineering, it is very difficult for someone without STEM education to pursue a career in STEM. There are good reasons to believe that the social determinants of STEM education, like the determinants of science careers, are different from those of general education (Xie 1989; Xie \& Shauman 2003; Xie \& Killewald 2012).

Hence, we propose a decomposition approach to understanding STEM education. First, we ask what social determinants and processes affect educational attainment in general. Second, we ask what social determinants and processes affect attainment of STEM education relative to non-STEM education conditional on general educational attainment. The second component is analogous to "horizontal stratification" in postsecondary education (Gerber \& Cheung 2008). This approach admittedly works better at the college than at the precollege level, since mathematics and science are inseparable from general education in the elementary and secondary curriculum. It is at the college level that students begin to specialize into disciplinary tracks, and only a small fraction chooses STEM fields (Xie \& Shauman 2003; Xie \& Killewald 2012). This decomposition helps organize the different strands of the literature relevant to STEM education, so we apply it as a general framework for this review. 


\section{The Social Determinants of Education in General}

We briefly review the literature on the social determinants of educational attainment in order to frame our review of the influences on STEM educational attainment. Many comprehensive reviews of research on educational attainment and stratification are available for readers seeking more complete overviews (Bowles \& Gintis 1976; Hallinan 1988; Kao \& Thompson 2003; Buchman et al. 2008; Grodsky et al. 2008).

\section{Contextual Factors}

Student outcomes are dependent on the characteristics of the social settings in which they are situated. The study of educational attainment has largely examined the effects of factors operating at two somewhat overlapping contexts: residential neighborhood and school.

Studies document that neighborhood disadvantage, commonly measured using such contextual variables as neighborhood-level poverty rate, affects children's cognitive ability (Brooks-Gunn et al. 1993; Sharkey \& Elwert 2011), verbal ability (Sampson et al. 2008), academic achievement (Sastry \& Pebly 2010), and high school graduation (Harding 2003). Even more concerning is evidence that residential segregation by family income has substantially increased in the past three decades (Reardon \& Bischoff 2011), placing children living in poor neighborhoods at a severe disadvantage in educational attainment (Reardon 2011). Along with socio-economic segregation, racial segregation in America has long been known to severely disadvantaged African-Americans (Massey 1993) because it concentrates them in poor and disadvantaged neighborhoods.

Young people spend more waking hours in school than in any other setting, and sociologists have long been interested in the effects of school characteristics on achievement and identity formation (Coleman 1968). Many studies demonstrate that school characteristics affect students' academic outcomes (Raudenbush \& Bryk 1986; Hedges et al. 1994; Greenwald et al. 1996; Lauen \& Gaddis 2013), although the causal mechanisms driving the associations and the degree to which the effects operate through schools' economic resources (e.g., Hanushek, 1989) have yet to be fully identified. Net of family-level factors, school-level effects are found inconsistently but indicate that school resources matter. Small classroom size significantly improves students' academic achievement (Krueger 2003), and comparisons of academic growth in summer versus non-summer months show that schools may reduce inequalities associated with socioeconomic status (Downey et al. 2004). But inequalities by race appear more resistant to school resources (Downey et al. 2004), and schools may reinforce inequalities through curricular tracking (Gamoran \& Mare 1989). The complex influence of school context is illustrated by studies showing that the academic performance of low-income students, particularly African-American and Latino students, may be negatively affected by the proportion of middle- and upper-class students in the schools they attend (Crosnoe 2009).

Teachers, a fundamental school resource, are believed to influence students' educational outcomes. The influence of teachers, however, figures more prominently in personal accounts and qualitative research than in quantitative analyses since the influences are likely to be specific to individual teachers and thus hard to quantify and distinguish from potential 
confounders. A conventional method is to measure teacher quality with teacher's observed characteristics such as age, degree, teaching experience, professional training, and salary (NCES 2012). There is evidence that teacher quality significantly improves students' academic achievement, net of family socioeconomic background (Darling-Hammond 1999; Wayne \& Youngs 2003; Rockoff 2004).

\section{Family Influences}

The importance of the family for educational outcomes is well established in sociology. The classic Blau-Duncan (1967) and Wisconsin (Sewell et al. 1969; Hauser et al. 1983) models of status attainment codified the influence of parents' education and occupation on the educational attainment of their children. Subsequent analyses have affirmed the classic models and extended them through the study of racial differences (Alexander et al. 1994), consideration of mediating mechanisms (e.g., McLoyd 1998; Hill \& Tyson 2009; Greenman et al. 2011; Roska \& Potter 2011), multi-generational influences (Jæger 2012), and how the influence of family changes over time (Reardon 2011). Aspects of family structure, including single-parent headship (Astone \& McLanahan 1991; Kim 2011) and number of siblings (Blake 1989; Downey 1995; Steelman et al. 2002) are shown to influence educational outcomes regardless of socioeconomic status.

A great deal of research focuses on identifying the causal mechanisms through which family influences operate. Studies often pit the direct effect of families' economic resources, i.e., how much parents invest in their children's education and development (Becker 1991; Duncan et al. 1994; Kaushal et al. 2011) against the effects of class-based cultural and social resources, i.e., class-based differences in parenting practices and opportunities for skillbuilding (Mayer 1997; Jæger 2011; Lareau 2011) and the development of non-cognitive "soft" skills, as well as cognitive skills (Cunha \& Heckman 2009; DiPrete \& Jennings 2012; Turney \& McLanahan 2012; Heckman et al. 2013; Hsin \& Xie 2014). By non-cognitive skills researchers mean a variety of psychological traits that affect one's behavior towards learning and work. Examples include interest in the subject area, ambition, expectation, conscientiousness, persistence, self-control, and a range of social skills that affect performance in social settings. ${ }^{1}$ In addition, the influence of family structure is often interpreted as evidence that social capital (Coleman 1988), i.e., social connections that bring information and emotional support, is the mechanism through which family affects educational outcomes (Dika \& Singh 2002). Empirical evidence supports each of these perspectives and indicates that they are interrelated rather than competing. For example, parental beliefs and behaviors may mediate the influence of parental socioeconomic status, as can practices construed as "concerted cultivation" (Bodovski \& Farkas 2008; Lareau 2011) or, more generally, "parental involvement" (Jeynes 2005).

\section{Individual-Level Factors}

Myriad individual characteristics influence educational outcomes. The important individuallevel influences range from cognitive to non-cognitive skills, from physical to mental health,

\footnotetext{
${ }^{1}$ The word "non-cognitive" may be misleading because the formation of these attitudes and their influences on behaviors surely involve cognition. The term is now commonly used in economics and sociology.
} 
and from personality to physical characteristics. What is less obvious is the relative degree to which these characteristics are inborn or developed; this "nature vs. nurture" debate has been ongoing in social science since the $19^{\text {th }}$ century (Plomin et al. 1994) and is unlikely to be resolved in the foreseeable future. We briefly summarize the research in two broad categories of individual influences - cognitive ability, or intelligence, and social psychological, or "non-cognitive," factors - and point readers to Farkas (2003) for a more thorough review of these influences on social stratification outcomes.

Broadly speaking, cognitive ability refers to aptitude with mental tasks such as problemsolving, comprehension, reasoning, knowledge acquisition, abstract thought, and connection-making. Cognitive ability is strongly associated with children's academic performance (Cain et al. 2004; Deary et al. 2007; Rohde \& Thompson 2007; Koenig et al. 2008) and a broad range of educational outcomes, including student performance, university entry and completion, and overall educational attainment (Jencks et al. 1979; Marks 2013) even when socioeconomic background is controlled. Of course, the strong association between cognitive ability and educational outcomes does not settle the nature-nurture debate or the issue of how intelligence is related to social environment (see Nisbett 2009 for an extensive review).

Interest in the influence of non-cognitive skills has grown in recent years (Cunha \& Heckman 2009; DiPrete \& Jennings 2012; Turney \& McLanahan 2012; Heckman et al. 2013; Hsin \& Xie 2014). However, it should be noted that stratification researchers in sociology have long studied the role of psychological traits for socioeconomic achievement. The classic Wisconsin model highlights the importance of future educational and occupational expectation as predictors of future educational success (Sewell et al. 1969; Hauser et al. 1983). Others have added attention and responsiveness to performance feedback (Alexander et al. 1994) and self-discipline (Duckworth \& Seligman 2005) to the list. There is some evidence that the enhancement of children's non-cognitive, rather than cognitive, skills is the primary driver of the later life benefits of the early educational interventions for at-risk children (Heckman et al. 2013).

\section{The Social Determinants of STEM versus non-STEM in Education}

In this section, we examine how the set of factors known to affect general education is related to involvement and achievement in STEM education.

\section{Contextual Factors}

Social and institutional environments matter for STEM educational outcomes just as they do for general education, but research on the influential contextual factors for STEM education has been narrowly focused on school-specific factors that are expected to affect participation and achievement in STEM education. Thus, although there is evidence that neighborhood disadvantage, for example, is associated with lower math achievement in primary school (e.g., Catasmbis \& Beveridge 2001; Greenman et al. 2011), little is known about other potential contextual factors, such as local labor market characteristics or proximity to science-focused industry. 
Schools differ widely in resources for STEM education, such as teacher quality and science labs, primarily reflecting cross-school inequalities in family SES of students. ${ }^{2}$ Studies of the elementary and secondary schools suggest that funding and resource availability shapes the extent to which students engage in and excel at STEM education (Oakes 1990; Museus et al. 2011; Wang 2013). The current research largely focuses on the structural effect of resources: well-resourced schools offer relatively wide arrays of math and sciences courses, and greater access to resources such as textbooks and scientific lab equipment (Oakes \& Saunders 2004), but their effect on learning cultures or promotion of STEM education has receive much less attention (Wang 2013; Legewie \& DiPrete 2014a). School resources are also positively associated with staffing of high quality teachers (Clotfelter et al. 2005; NCES 2013c). Numerous studies show that access to knowledgeable and experienced math and science teachers positively impacts both student learning (Darling-Hammond 1999; Wayne \& Youngs 2003; Hill et al. 2005; Hattie 2008; Sadler et al. 2013) and student interest in and passion for science (Woolnough 1994; Osborne 2003; Maltese \& Tai 2011; Tytler \& Osborne 2012; Sjaastad 2012). Although the studies often suffer from potential confounders (e.g., selection), together they provide compelling evidence that school context predicts achievement in STEM education.

Higher education research similarly shows that characteristics of institutional context and climate affect students' pursuit of and persistence in a STEM major (Hurtado \& Carter 1997; Seymour \& Hewitt 1997; Chang et al. 2014). Unsupportive campus climates, highly competitive classrooms, poor instruction, and excessive workloads, can diminish academic engagement, achievement, and persistence to degree (Seymour \& Hewitt 1997; Cabrera et al. 1999; Carlone \&Johnson 2007; Chang et al. 2011; Chang et al. 2014). These negative contextual characteristics may be more common in STEM coursework than in non-STEM coursework, particularly in introductory or "weeder" classes (Seymour \& Hewitt 1997) and in selective universities than in non-selective universities (Chang et al. 2008), pushing otherwise capable and interested students towards non-STEM majors (Carlone \& Johnson 2007; Chang et al. 2011) or out of postsecondary education altogether (Hurtado \& Carter 1997). Postsecondary environments in which students receive engaging instruction, encouragement from faculty and other students, sufficient financial aid and networking opportunities are positively associated with STEM engagement and persistence (Seymour \& Hewitt 1997; Museus et al. 2011; Graham et al. 2013; Chang et al. 2011). The opportunity to collaborate with faculty on undergraduate research projects may be especially effective for building a student's confidence and identification with the scientific community (Grandy 1998; Chang et al. 2011; Graham et al. 2013). More importantly, these programmatic investments may improve the persistence of students in STEM college majors.

Moving forward, further research is needed to identify institutional factors that causally promote students' engagement with and achievement in STEM education. It is particularly necessary to refrain from interpreting as causal the observed associations of institutional characteristics with students' outcomes in STEM education, for they may be confounded by the selective sorting of students into different institutions. Once causal mechanisms are

\footnotetext{
${ }^{2}$ Research shows that rural schools do not lag urban schools in math education (NCES 2007).
} 
known, effective policies may be formulated to promote STEM education. Further, it will be fruitful to know how institutional factors affect STEM education versus non-STEM education, conditional upon their effects on general education.

\section{Family Factors}

As with general education, family factors-particularly family socioeconomic status (SES) - is strongly associated with students' achievement in math and science, interest in STEM higher education, and attainment of a STEM degree. Recent reports and studies drawing on current data confirm this relationship: substantial differences in STEM coursework participation and achievement persist between students from low-SES and high-SES backgrounds throughout the STEM pipeline (Schneider et al. 1998; Mulligan et al. 2012; Miller \& Kimmel. 2012; NSB 2014). But the specific mechanisms through which family SES influences STEM education are no clearer than they are for general education.

One prominent explanation posits that the relatively high levels of education and income that characterize middle- and high-SES families enable them to provide their children with the encouragement, support, exposure to science, and access to STEM enrichment experiences necessary to develop and sustain early interest, confidence and aspirations in STEM (Turner et al. 2004; Harackiewicz et al. 2012; Archer et al. 2012; Sjaastad 2012; Dabney et. al 2013). Some researchers further suggest that middle-class parenting strategies and resources may promote a worldview that enables children to view science as a "thinkable/natural" career choice (Archer et al. 2012). The family influence on youths' social-psychological orientation may be particularly important for promoting math and science achievement and persistence in the STEM pipeline (Tai et al. 2006; Mau 2003; Wang 2013; see below for further discussion).

While there is clear empirical evidence that family background affects STEM engagement and achievement early in the life course, it is unclear how far into the educational and/or career trajectory such effects extend. Descriptive analyses suggest that SES continues to exert an important influence well beyond primary and secondary school since high-SES students make up a disproportionate percentage of those obtaining STEM degrees and pursuing STEM careers (Ware \& Lee 1988; Chen 2009). But these results are confounded by the fact that high-SES students are more likely to matriculate and complete college. Multivariate analyses show that differences by family socioeconomic background in STEM interest and persistence during postsecondary education disappear when other factors, such as academic achievement, are controlled (Mau 2003; Ma 2009; Xie \& Killewald 2012; Chen $\&$ Soldner 2014). Thus, recent research suggests that family background plays an influential role in acquiring the academic skills necessary to attain a postsecondary degree but it does not play a direct role in the pursuit and attainment of a STEM degree specifically.

The field will benefit from more research attempting to understand the specific mechanisms through which family background impacts STEM engagement, particularly at a young age. As we have argued, this appears to be the period in which family background exerts a particularly strong effect on STEM education. Researchers should also further explore how family influences may be highly heterogeneous - varying across different families, say by family-level characteristics beyond what is usually captured in conventional SES measures, 
such as cultural values, parent-child relations, or individual-level characteristics (discussed below).

\section{Individual Factors}

Individual cognitive ability, spatial ability, numeracy, or other indicators of basic cognitive functions (Spelke 2005) are all closely correlated with both achievement in math and science courses in compulsory and postsecondary education and scores on standardized math and science tests (Deary et al. 2007; Lynn \& Mikk 2009; Wai et al. 2010; Reilly \& Neumann 2013). Spatial thinking is assumed to be an important determinant of achievement in STEM education, and it has also been linked to interest and confidence in math and science (Wai et al. 2010). However, the assumption that spatial and quantitative aptitude are uniquely essential prerequisites for achievement in STEM is not without critics (see Spelke 2005), nor is the assumption that individual capacity for these cognitive skills innate and fixed. A growing body of research examines the malleability of fundamental cognitive skills such as spatial thinking (e.g., Newcome 2010) and points to new areas for investigation.

Researchers now recognize particular individual social psychological characteristics that are strongly related to engagement and achievement in STEM education (e.g., Tai et al. 2006; Maltese \& Tai 2011; Wang 2013). These include math and science self-concept, interest in science, and aspirations for a science-related career. Science self-concept, or self-reflexive beliefs about one's math and science abilities, predicts participation in challenging STEM courses, pursuit, persistence and attainment of STEM degrees, and entrance into STEM careers (Correll 2001; Mau 2003; Maltese \& Tai 2011; Cech et al. 2011; Wang 2013). Interest in math/science or aspirations for a STEM-type career are strongly predictive of STEM educational outcomes (Maple \& Stage 1991; Mau 2003; Xie \& Shauman 2003; Tai et al. 2006; Maltese \& Tai 2010; Maltese \& Tai 2011; Xie \& Killewald 2012). In particular, aspiring to a science career appears to be a prerequisite to attainment of a STEM degree (Xie \& Shauman 2003; Tai et al. 2006), and loss of interest is a main reason for attrition from STEM majors (Seymour \& Hewitt, 1997). In addition, researchers have recently defined the concept of "science identity" - the sense that science is "right" for an individual, or that an individual is "right" for science - and recognized its impact on STEM educational outcomes (Cole \& Espinoza 2008; Cech et al. 2011; Archer et al. 2012; Perez et al. 2014). Science identity is hypothesized to form early but to influence engagement with STEM education and careers throughout the life course (Cech et al. 2011; Archer et al. 2012; Perez et al. 2014). The fact that each of these non-cognitive influences remains significant even after controlling for academic achievement (Xie \& Shauman 2003; Simpkins et al. 2006; Cech et al. 2011; Wang 2013) attests to the significance of affective, or psychosocial, influences on STEM educational outcomes. Continued research on the social psychological determinants of STEM education, particularly as they emerge and evolve over the life course, will shed new light on individual differences in STEM education - why certain people and groups excel in STEM education while others do not.

\section{International Comparisons of STEM Education}

Comparing STEM education in the U.S. to that in other countries is a complicated matter to which both the public and policy circles have paid a great deal of attention. These 
comparisons have been sparked by the relatively mediocre performance of American students on international standardized mathematics and science tests (OECD 2010; Hanushek et al. 2010; NCES 2011, 2013a; Killewald \& Xie 2013; NSB 2014). The disappointing performance of U.S. students is surprising to many, given the wealth of the U.S. relative to that of many better-performing countries, such as Taiwan, Finland, and Hungary (Hanushek et. al 2010; Killewald \& Xie 2013). The surprise and public outcry also stems from the belief that the U.S. has been the world leader in science for more than eighty years (Xie \& Killewald 2012). How could the U.S. be beaten by other countries at its own game? Given the U.S. students' mediocre test performances, will the U.S. remain competitive in science and the knowledge-driven economy? Worrisome speculation about these questions popularized the report, Rising above the Gathering Storm (NAS 2007), and prompted renewed attention to STEM education in the U.S.

A review of the large literature on international comparison of STEM education is beyond the scope of this article. Interested readers can find discussions in the NAS et al. report (2007), as well as responses by Killewald \& Xie (2013) and Xie \& Killewald (2012). Many studies that explore the achievement differences between the U.S. and higher-performing countries find that U.S. students are disadvantaged on many factors that affect math and science achievement. These factors include national cultural traditions related to math and science (Stevenson \& Stigler 1992; Cogan \& Schmidt (2002; Fang et al. 2013), family and school support for and emphasis on math and science education (Tsui 2005; Fuchs \& Wößmann 2007; Sousa et al. 2012;), the structure of the educational system and national labor market conditions (Langen \& Dekkers 2005), and cross-country differences in teaching style and curriculum (NCES 2000; 2006; Schmidt 2012).

\section{Gender and STEM Education}

Despite robust progress toward equity, gender disparities continue to be a defining characteristic of STEM education. In this section, we review the trends in the gender gaps in STEM achievement, participation, and interest, and synthesize the research aimed at explaining these gaps.

\section{Gender Gaps in STEM Achievement}

Achievement is commonly measured with standardized test scores and course grades in math and science. Studies have long shown that female students' math and science grades are equal to or better than those of their male classmates throughout elementary and secondary school (Kenney-Benson et al. 2006; Shettle et al. 2007). Early studies of standardized test performance also showed gender parity, or a slight female advantage, in basic computation and understanding of math concepts throughout grades K-12 (Hyde et al. 1990a; Hedges \& Nowell 1995). Yet, gender gaps in three aspects of achievement dominate the perception of gender and STEM and are often cited as evidence of innate male superiority in STEM education (Correll 2001; Nosek et al. 2002; Hyde 2005): (1) a male advantage in complex problem-solving skills during high school (Hyde et al. 1990a), (2) greater variability in males' test scores and a resulting preponderance of boys among the highest scorers (Hedges and Nowell 1995; Xie and Shauman 2003; Penner 2008; Penner \& Paret 2008; Ellison \& Swanson 2010; Robertson et al. 2010; Wai et al. 2010), and (3) a male 
advantage on spatial abilities (Linn \& Petersen 1985; Hyde 2005; Spelke 2005; Halpern et al. 2007).

Recent analyses challenge the ideas that the observed gender gaps in STEM achievement are immutable and that they are socially significant. There has been a secular decline in the overrepresentation of males in the upper tail of the achievement distributions (Hyde et al. 2008; Hyde \& Mertz 2009; Lindberg et al. 2010) and the presence and size of the upper tail disparity varies substantially across countries, race, and socioeconomic status (Penner 2008; Penner \& Paret 2008). In-depth studies of spatial abilities document female (as well as male) advantages on specific tasks, that all gaps are consistently small, and that performance on all tasks is sensitive to training (Hyde 2005; Spelke 2005; Halpern et al. 2007). The social significance of the documented gender disparities in achievement remains unclear, as these disparities are shown to have limited power to explain those in STEM participation (Xie \& Shauman 2003; Weinberger 2005). Commonly used standardized tests may be poor instruments for measuring gender differences in STEM aptitude (Gallagher et al. 2002; Halpern 2002), since research suggests that item content may bias the scores (Chipman 2005; Spelke 2005), and that they have limited power to predict actual task performance and STEM achievement for girls (Schmidt 2011). Recent research also highlights the need to estimate the potential influence of math or science achievement in relation to achievement in other domains (Lubinski \& Benbow 2006; Riegle-Crumb et al. 2012; Wang et al. 2013).

\section{Gender Gaps in STEM Participation}

Participation in STEM education is conventionally measured in terms of high school math and science course completion and postsecondary choice of major and degree field, and the size of the gender gap varies across these measures. Gender gaps in high school math participation have disappeared, as female students are now more likely than their male peers to complete precalculus and algebra II and are equally likely to complete calculus (NSB 2012; NSB 2014). In high school science, girls continue to be overrepresented in advanced biology and underrepresented in physics, but these completion disparities have declined significantly (NSB 2012; NSB 2014). Despite growing equality in high school coursework, however, wide gaps in STEM participation remain in tertiary education. Thus far, growth in women's participation in STEM majors has been driven mainly by the general increasing enrollment of women (Mann \& DiPrete 2013) and declining gender gaps in persistence in the "science pipeline" during college and into post-baccalaureate education (Miller \& Wai 2015). Consequently, while the number of women earning undergraduate and graduate degrees in STEM fields has steadily increased, the proportionate representation of women in many STEM fields has not increased since the 1980s (England \& Li 2006; England et al. 2007; DiPrete \& Buchmann 2013; Mann \& DiPrete 2013) and may be declining in some engineering fields (Mann \& DiPrete 2013). Women in the U.S. and other industrialized countries have earned the majority of biological and social science degrees since the 1980s, but they remain significantly underrepresented among degree recipients in engineering, the physical sciences, math, and computer science (Charles \& Bradley 2002, 2006, 2009; Xie \& Shauman 2003; Xie \& Killewald 2012; DiPrete \& Buchmann 2013). 
Completion of advanced math and science classes remains one of the strongest predictors of students' scores on achievement tests and pursuit of postsecondary STEM degrees (Xie \& Shauman 2003; Bozick \& Lauff 2007; Chen 2009). But the association between secondary STEM course completion and grades and postsecondary STEM participation is much stronger for males than for females (Xie \& Shauman 2003; Riegle-Crumb et al. 2012; Morgan et al. 2013; Mann \& DiPrete 2013), i.e., gender parity in preparation does not translate into gender parity in persistence in STEM education. The continuing gender gaps in postsecondary STEM education suggests that we do not yet fully understand the processes that promote persistence in STEM education and how those processes vary by gender. This highlights a need for empirical assessments of the qualitative aspects of "participation," i.e., of the in-class interactions and experiences that may reinforce or generate gender disparities among young women and men who are equally prepared to pursue postsecondary STEM education but do so at very unequal rates.

\section{Gender Gaps in STEM Interest and Affect}

In contrast to the trend toward gender equality in math/science achievement and STEM participation in many domains, significant gaps in math/science interest and affect endure. The notion that males are naturally more talented and interested in science is a widespread cultural stereotype (Nosek et al. 2009; Leslie et al. 2015), and although most people consciously reject it (Hyde et al. 1990b), implicit association studies confirm the ubiquity of the "math = male" stereotype across age, race/ethnicity, gender, and country (Nosek et al. 2002; Kiefer \& Sekaquaptewa 2007; Nosek et al. 2009; Cvencek et al. 2011). Reflecting this normative belief, girls consistently report lower self-assessments of quantitative skills, lower self-confidence in math abilities, less interest and less motivation to learn math and science, and higher levels of math anxiety than their male peers, as well as less interest in pursuing careers in STEM fields, even after controlling for achievement (Correll 2001, 2004; Fredricks \& Eccles 2002; Watt, 2004, 2006; Jacobs et al. 2006; Else-Quest et al. 2010; Riegle-Crumb et al. 2011; Sadler et al. 2012; Wang et al. 2013). Girls also are more likely than boys to express interest in pursuing people-oriented work, to see science as inconsistent with that orientation, and to perceive the scientific lifestyle as unattractive (Miller et al. 2006).

Gender disparities in social psychological determinants of STEM education manifest in consequential ways at the more advanced levels of education. For example, Cech et al. (2011) find that among college engineering majors, women have lesser "professional role confidence" than do men. In addition to the gender gaps in STEM-specific affect, recent scholarship shows how disparities in seemingly unrelated affective characteristics, such as the relative female aversion to competition (Gneezy et al. 2003; Gneezy \& Rustichini 2004; Niederle \& Vesterlund 2007;) and risk-taking (Croson \& Gneezy 2009), contribute to gender gaps in STEM education (Niederle \& Vesterlund 2010; Alon \& DiPrete 2013).

\section{Explanations of the gender gaps in STEM education}

The early literature often attributed gender gaps in postsecondary STEM education to gender differences in precollege math and science achievement and participation. As the gaps in test scores and course-taking closed, however, this explanation lost its power (Xie \& Shauman 
2003; Riegle-Crumb et al. 2012; Morgan et al. 2013). Despite the perennial quest for biologically-based gender differences in science and math aptitudes (Baron-Cohen 2003; Ceci et al. 2009; Ceci \& Williams 2010; Valla \& Ceci 2011), essentialist "innate ability" explanations have been undermined by a large body of empirical work (Hyde 2005; Spelke 2005; Ceci et al. 2009). Over the past decade, the effort to explain gender inequities in STEM education has increasingly focused on the determinants and influence of interest in science and math, as the primary determinant of sex differences in STEM education. Early life course interest in STEM is strongly associated with participation in STEM education (Tai et al. 2006), and the large gender gap in STEM interest during high school is strongly associated with the gender gap in postsecondary STEM education (Xie \& Shauman 2003; Ma 2011; Perez-Felkner et al. 2012; Sadler et al. 2012; Legewie \& DiPrete 2014b). What, then, explains the gender gap in interest in STEM education?

Essentialist explanations posit that the "interest gap" is a natural outgrowth of biologicallybased sex-typed predispositions. One prominent theory argues that prenatal hormonal exposure predisposes females to a natural affinity for interacting with people and caring relationships and males to an innate interest in inanimate, technical and mechanical things (Baron-Cohen 2003; Su et al. 2009; Schmidt 2011). Another posits that the interest gap is linked to the biological requisites of childbearing which cause females to naturally prioritize family over work roles (Ceci et al. 2009; Ceci \& Williams 2010, 2011). Recent scholarship does not support these essentialist explanations. Research shows that interest in STEM is highly responsive to environmental influences (Cheryan et al. 2009, 2011; Murphy et al. 2007; Stout et al. 2011). Questions have also been raised concerning the validity and reliability of measures commonly used in this line of research, such as the person-thing construct and similar bipolar interest scales (e.g., data-ideas) (Tay et al. 2011; Valian 2014). Further, although gender differences in work-life preferences are pervasive, they do not explain gender gaps in STEM interest or participation (Xie \& Shauman 2003; Frome et al. 2006, 2008; Cech et al. 2011; Riegle-Crumb et al. 2012; Perez-Felkner et al. 2012; Morgan et al. 2013; Mann \& DiPrete 2013).

Social psychological and social cultural perspectives offer more nuanced explanations of the interest gap. For example, expectancy-value and expectation-states theories emphasize the influence of cultural milieu, the interactional nature of interest formation and persistence, and the cumulative influence of these processes on both individual outcomes and the structures of opportunity in STEM education (Ridgeway \& Correll 2004; Shepherd, 2011; Eccles 2011a, 2011b; Ridgeway 2014). Extensive analyses of cross-national data confirm the importance of cultural beliefs as predicted by these theories: gender gaps in STEM achievement, interest, and postsecondary participation are strongly associated with nationallevel measures of adherence to implicit male=math stereotypes (Nosek et al. 2009) and gender-essentialist ideology (Charles \& Bradley 2009; Charles et al. 2014) as well as indicators of social and economic gender equity (Guiso et al. 2008; Penner 2008; Else-Quest et al. 2010). Studies indicate that macro-level cultural conditions affect gender differences in STEM interest through a variety of causal mechanisms: they are encoded in and conveyed through parents', teachers', and significant others' attitudes and expectations (Fredricks \& Eccles 2002; Herbert \& Stipek 2005; Jacobs et al. 2005; Jacobs et al. 2006; Riegle-Crumb \& 
Humphries 2012; Lavy \& Sand 2015), pervasive cultural cues about scientists (Murphy et al. 2007; Cheryan et al. 2009; Beilock et al. 2010; Stout et al. 2011; Cheryan et al. 2011), the dearth of positive female role models and mentors (Carrell et al. 2010), and school environments and friend networks (Riegle-Crumb et al. 2006; Legewie \& DiPrete 2014a).

The causal link between cultural beliefs and STEM interest is well demonstrated in studies of stereotype and identity threat (Nosek et al. 2002; Aronson \& McGlone 2008; Nguyen \& Ryan 2008) and occupational preference formation (Correll 2001, 2004). In particular, expectation-states theory (Ridgeway 2014) posits that cultural stereotypes structure inequality by generating implicit bias in evaluation, association preferences that segregate networks, and interpersonal hostility toward individual members of negatively stereotyped groups. Recent studies document that female students face negative biases in the grading of their school work (Lavy \& Sand 2015) and evaluation of their competence and qualification for STEM employment (Moss-Racusin et al. 2012; Knobloch-Westerwick et al. 2013; Reuben et al. 2014), and gender segregated networks and "chilly" climates in STEM higher education and workplaces (Steele et al. 2002; Logel et al. 2009; Koput \& Gutek 2010; Sheltzer \& Smith 2014). Future research should focus more on identifying the nature, timing, and relative impacts of these processes to develop effective practices that foster and sustain interest in STEM among girls and women.

\section{Racial and ethnic differences in STEM education}

Despite significant gains in the participation of underrepresented minorities (URMs) African-American, Hispanic, and Native-Americans - in STEM education, they continue to be underrepresented in the STEM pipeline and to lag behind Whites and Asians in STEM and general achievement (NSB 2014; Chen and Soldner 2014).

\section{Racial Gaps in STEM Achievement}

Reports indicate that while URMs have made tremendous strides in terms of narrowing the racial gap with Whites and Asians in math and science test scores, course participation, and course grades, significant differences still remain (Nord et. al 2011; NCES 2013b). Test score disparities begin to emerge as early as kindergarten and generally become more pronounced as students progress through the school system (Jencks \& Phillips 1998; Fryer \& Levitt 2004; Reardon 2008). Performance in math and science coursework follows a similar pattern, with Asians and Whites typically earning significantly higher average grades than URMs throughout the school years (Kao \& Thompson 2003; Nord et al. 2011). Taken together, these achievement gaps play a major role in limiting the participation of URMs in STEM education (Museus et al. 2011; Riegle-Crumble \& King 2010; Xie \& Killewald 2012).

The aggregate trends also mask important heterogeneity, which is the subject of a growing body of research on URMs. For example, recent studies show that URM disadvantage is most pronounced, both in magnitude and in rate of divergence, among high achieving students (Hedges \& Nowell 1999; Neal 2005; Reardon 2008; Riegle-Crumb \& Grodsky 2010). Reardon (2008) finds that among elementary-school students, the black-white gap in math achievement grew twice as fast among high achieving students as among low- 
achieving students. The fact that the most talented URMs fall behind the fastest is perhaps more alarming than the aggregate racial gap, given that the high-performing students have the greatest potential to excel in subsequent STEM education. Moreover, it raises important questions about whether these students are receiving access to opportunities and resources needed to keep pace with their peers.

\section{Racial Gaps in STEM Participation}

At the K-12 level, URM students tend to take fewer and less challenging math and science courses than their white and Asian peers (Kelly 2009; Riegle-Crumb \& Grodsky 2010; Nord et al. 2011; NSB 2014) and are significantly more likely to be placed in remedial and lowtrack math and science courses (Oakes 1990; Kao \& Thompson 2003). The racial/ethnic gap in advanced coursework is strongly associated with racial/ethnic gaps in standardized test performance (Gamoran \& Mare 1989; Kao \& Thompson 2003) and interest in STEM majors and careers (Miller \& Kimmel 2012; Wang 2013). The overrepresentation of URMs in remedial courses reinforces these gaps, as these courses focus on basic knowledge and rote memorization (Oakes 1990; Kao \& Thompson 2003).

At the post-secondary level, the number of URMs entering college and obtaining STEM degrees has steadily grown over time. For example, the share of URMs among all recipients of science and engineering bachelor's degrees grew from 17\% in 2000 to 20\% in 2011 (NSB 2014). Still, URM students are underrepresented because their share in the general population ages 25-29 is much higher, above 36\% in 2011 (U.S. Census Bureau 2014). Furthermore, among all STEM degree-holders, URMs are overrepresented among those who attend two-year and less prestigious four-year institutions (Reardon et. al 2012; Chen \& Soldner 2014). In particular, a large proportion of URMs pursue and attain STEM degrees at minority-serving and historically black colleges (NSB 2014), which often provide a more supportive and welcoming campus climate than traditional universities (Allen 1992; Hurtado 1992). The implications of the racial/ethnic differences in institutional affiliation are not well-understood, but since elite graduate programs and industries disproportionately draw from elite mainstream universities, these differences may have important implications for stratification within graduate school and the workforce.

\section{Racial Gaps in STEM Interest and Affect}

While interest in STEM is highest among Asians (Xie \& Goyette 2003; DeWitt et al. 2011), studies at all levels of education indicate that URMs express enthusiasm for STEM education and careers on par with their Whites peers, despite the formers' lower levels of achievement (Riegle-Crumb et al. 2011; Riegle-Crumb \& King 2010; NSB 2014). For instance, a report by the National Science Board shows that since at least 1995, URM college students have pursued STEM majors at rates comparable to those of White students (NSB 2014). Other studies of racial/ethnic differences in affective orientations toward STEM result in similarly paradoxical findings: although rates of participation and achievement are disproportionately low among URMs, their levels of self-confidence and enjoyment of math are disproportionately high (Riegle-Crumb et al. 2011). 


\section{Explanations of the racial gaps in STEM education}

In general, there are two broad explanations for the racial disparities in STEM education. The first attributes the gaps to URM students' lower levels of interest in and enjoyment of science. As we have already demonstrated, however, we find little evidence to support this hypothesis. Instead, mounting evidence suggests that social psychological factors may limit the extent to which URM students are able to convert their interests into meaningful STEM engagement. For example, studies show that while adolescent URMs express a level of interest in science that resembles that of their White peers (Riegle-Crumb et al. 2011), URM youth lack opportunities and family resources to develop a deep connection with science (Aschbacher et. al 2010; Archer et. al 2012).

Social-psychological factors may become even more important during post-secondary education, since individual choice plays a larger role in persistence at this educational stage. Studies reveal that URM students in STEM majors at the post-secondary level often struggle with feelings of isolation (Seymour \& Hewitt 1997) and have difficulty adapting to the white, middle-class culture of science (Carlone \& Johnson 2007; Chang et al. 2011; Chang et al. 2014). The hurdles - both the structural and the social-psychological - to young URM scholars' full integration into the scientific community (Tinto 1987; Graham et al. 2013) have negative effects on their academic confidence, engagement, and likelihood of persisting in STEM (Carlone \& Johnson 2007; Chang et al. 2014).

The second explanation attributes these racial gaps to URM students' lower levels of academic preparation at the K-12 level, which limits their attainment of both general and STEM education at the college and advanced levels. Differences in K-12 mathematics achievement may be especially consequential, as research has shown this to be one of the single best predictors of success in college (Adelman 1999, 2006). After controlling for these disparities in precollege academic performance, studies indicate that URMs are actually more likely than Whites to (1) enroll in college (NCES 2012) and (2) declare a STEM major (Riegle-Crumble \& King 2012). Furthermore, conditional on degree attainment, it appears that URMs choose fields of study, including STEM, at rates similar to those of Whites (NSB 2014; Xie \& Killewald 2012). Identifying the causes of the racial preparation gap is, therefore, key to understanding racial gaps in both general education and STEM education at the college and advanced levels.

The most controversial explanation for racial disparities in academic performance focuses on genetic or otherwise innate differences in cognitive abilities such as general intelligence (e.g., Herrnstein \& Murray 1994) or spatial thinking (e.g., Lynn 1996). Such explanations are generally met with skepticism, criticized as lacking empirical support and reflecting racist ideologies (e.g., Fischer et al. 1996), and rejected as implausible explanations for racial/ethnic gaps in STEM achievement and participation.

Sociological explanations of the racial preparation gap focuses on the structural causes of racial inequalities in access to the resources and opportunities that are more directly linked to STEM educational outcomes. Most often these explanations focus on two forms of structural inequality: social class differences that are closely correlated with race/ethnicity and school quality differences that are closely related to both race/ethnicity and social class. 
URM students are significantly overrepresented among relatively poor, less educated, underemployed families and those headed by single parents than are whites and Asians (Kao $\&$ Thompson 2003). Black, Hispanic, and Native-American youth are therefore less likely to be supported by financial and parental resources. The findings of numerous studies support this hypothesis by showing that after controlling for family SES, a large portion (but not all) of the racial achievement gap in math and science is eliminated (Jencks \& Phillips 1998; Kao \& Thompson 2003; Downey 2008; Hattie 2008).

Racial/ethnic segregation of schools at the primary and secondary levels has significant implications because it concentrates URM students in poorly funded, under-performing and understaffed schools (Condron \& Roscigno 2003; Logan et al. 2012; NCES 2013c). Higher representation of URM students is associated with multiple disadvantages, including fewer qualified teachers (Clotfelter et al. 2005; NCES 2013c; NSB 2014), fewer advanced courses (Wang 2013; NCES 2012), larger class sizes (NCES 2012), and outdated learning materials (Oakes 2004). The effect of these class-based disparities is compounded by racial/ethnic disparities within schools: URM students are more likely to be placed in low-track courses and their teachers tend to have low expectations for their learning (Tennebaum \& Ruck 2007). The combined effects of the class- and race-based disparities lead URM students to have higher rates of attrition from, as well as poorer performance in, the educational pipeline than Whites and Asians (Oakes 1990; NCES 2012).

We encourage researchers to seriously engage with both the structural and the socialpsychological explanations and to integrate both perspectives so as to achieve a more comprehensive understanding of racial disparities in STEM. To uncover the underlying causes of the observed racial differences in STEM education, a life course perspective is required to identify how racial gaps emerge in early childhood, grow along the educational ladder, and likely result from an accumulation of social advantage and disadvantage. Finally, better research is also needed to separate the effects of race versus those of family SES, as the two are highly correlated in U.S. society.

\section{Conclusion}

STEM education is a complicated social phenomenon. A vast literature in U.S. sociological research now exists on the state of STEM education, the primary focus of this review, though this is only a small part of the larger literature. We have categorized the literature into studies on two key components of STEM education - attainment of education in general and attainment of STEM education conditional on attainment of general education. In this concluding section we offer a few summary observations on the strengths and weaknesses of this literature.

First, the current literature is strong on the social determinants of general education and weak on the social determinants of STEM education conditional on general education. This is because research in sociology is mostly concerned with social inequality in attaining general education rather than STEM or any particular type of education. Second, more research is needed to explain the STEM achievement gap between the U.S. and other high performing countries. Because education is an important social institution whose success 
depends on many broad factors beyond schools, such as the family, labor market structure, culture, and international context, any attempt to find a single root cause for the perceived under-achievement of Americans students would be too simplistic. Sociology has had a long tradition of studying the influences of macro-level forces, such as social institutions, social context, and culture, on individuals' outcomes, and is thus uniquely situated to make important contributions towards understanding the STEM achievement gap between the U.S. and other countries. Third, while a great deal of research has studied the underachievement in STEM education of certain racial/ethnic groups and women, little attention has been paid to the reverse side of the issue: the determinants of the success of certain individuals and social groups in STEM education. We hope that researchers will fill these gaps in the future.

Research on STEM education is multi-disciplinary, but there is little integration across the many disciplinary streams of research on STEM education. Sociologists can and should learn from research in other fields on the topic. We have highlighted the important role that social psychological attributes appear to play in students' success in STEM education. This is an area from which sociologists have learned a great deal and will continue to learn. What are the economic returns to STEM education broadly defined (i.e., not necessarily STEM degrees)? Are students driven to acquire STEM education for its monetary returns or out of intellectual curiosity? To answer these questions, sociologists can learn from economists. Finally, sociological research on STEM education will benefit from a better understanding of how science and math classes are taught in schools at different levels. For this, sociology can learn from the large literature in education research. While intersecting with research in other fields, sociological research on the study of STEM education has already made important contributions to the field. However, it should be further expanded and improved, as concerns with the national competitiveness of the U.S. continue to be raised and discussed in the future. There are too many questions to which the current literature offers no satisfactory answers.

\section{Literature Cited}

Alexander KL, Entwisle DR, Bedinger SD. When expectations work: race and socioeconomic differences in school performance. Soc Psychol Q. 1994; 57(4):283-99.

Allen WR. The color of success: African-American college student outcomes at predominantly White and historically Black public colleges and universities. Harvard Educ Rev. 1992; 62(1):26-45.

Alon, S.; DiPrete, TA. Orientation vs behavior: gender differences in field of study choice set. Columbia University; 2013. Work. Pap.Available at: http://academiccommons.columbia.edu/ catalog/ac: 166692

Archer L, DeWitt J, Osborne J, Dillon J, Willis Beatrice, Wong B. Science aspirations, capital, and family habitus: how families shape children's engagement and identification with science. Amer Educ Res J. 2012; 49(5):881-908.

Aronson, J.; McGlone, MS. Stereotype and social identity threat. In: Nelson, TD., editor. The Handbook of Prejudice, Stereotyping, and Discrimination. New York, NY: Psychology Press; 2008. p. 153-78.

Aschbacher P, Li E, Roth EJ. Is science me? High school students' identities, participation and aspirations in science, engineering, and medicine. J of Res in Sci Teaching. 2010; 47(5):564-582.

Astone NM, McLanahan SS. Family structure, parental practices and high school completion. Am Soc Rev. 1991; 56(3):309-320. 
Autor DH, Katz LF, Kearney MS. Trends in U.S. wage inequality: revising the revisionists. Rev Econ and Stat. 2008; 90:300-23.

Baron-Cohen, S. The Essential Difference: The Truth about the Male and Female Brain. New York: Basic Books; 2003.

Becker, GS. Human Capital: A Theoretical and Empirical Analysis, with Special Reference to Education. New York: Columbia Univ. Press; 1964.

Becker, GS. A Treatise on the Family. Cambridge, MA: Harvard Univ. Press; 1991.

Beilock SL, Gunderson EA, Ramirez G, Levine SC. Female teachers' math anxiety affects girls' math achievement. Proc Natl Acad Sci. 2010; 107:1860-1863. [PubMed: 20133834]

Ben-David, J. The Scientist's Role in Society. Eaglewood Cliffs, NJ: Prentice Hall; 1971.

Blake J. Family size and quality of children. Demography. 1981; 18:421-442. [PubMed: 7308532]

Blake, J. Family Size and Achievement. Los Angeles: Univ. of California Press; 1989.

Blau, PM.; Duncan, OD. The American Occupational Structure. New York: Wiley and Sons; 1967.

Bodovski K, Farkas G. Concerted cultivation and unequal achievement in elementary school. Soc Sci Res. 2008; 37:903-19.

Boudon, R. Education, Opportunity and Social Inequality. New York: John Wiley \& Sons; 1974.

Bourdieu, P. Cultural reproduction and social reproduction. In: Karabel, J.; Halsey, AH., editors. Power and Ideology in Education. New York: Oxford Univ. Press; 1977. p. 487-511.

Bowles, S.; Gintis, H. Schooling in Capitalist America: Educational Reform and the Contradictions of Economic Life. New York: Basic Books; 1976.

Bozick, R.; Lauff, E. Education Longitudinal Study of 2002 (ELS:2002): A First Look at the Initial Postsecondary Experiences of the High School Sophomore Class of 2002. Washington, DC: Nat. Center for Educ. Statistics; 2007.

Brand J, Xie Y. Who benefits most from college? Evidence for negative selection in heterogeneous economic returns to higher education. Am Sociol Rev. 2010; 75:273-302. [PubMed: 20454549]

Breiner JM, Harkness SS, Johnson CC, Koehler CM. What is STEM? A discussion about conceptions of STEM in education and partnerships. School Science and Mathematics. 2012; 112(1):3-11.

Brooks-Gunn J, Duncan GJ, Klebanov PK, Sealand N. Do neighborhoods influence child and adolescent development? Am J of Sociol. 1993; 99(2):353-95.

Buchmann C, DiPrete TA, McDaniel A. Gender inequalities in education. Ann Rev of Sociol. 2008; 34:319-337.

Cabrera AF, Nora A, Terenzini PT, Pascarella E, Hagedorn LS. Campus racial climate and the adjustment of students to college: a comparison between White students and African-American students. J of Higher Educ. 1999; 70(2):134-60.

Cain K, Oakhill J, Bryant P. Children's reading comprehension ability: concurrent prediction by working memory, verbal ability, and component skills. J Educ Psychol. 2004; 96(1):31-42.

Card, D. The causal effect of education on earnings. In: Ashenfelter, O.; Card, D., editors. Handbook of Labor Economics. Vol. 3A. Amsterdam: Elsevier; 1999. p. 1801-1863.

Carlone HB, Johnson A. Understanding the science experiences of successful women of color: science identity as an analytic lens. J of Res in Sci Teaching. 2007; 44(8):1187-1218.

Carrell SE, Page ME, West JE. Sex and science: how professor gender perpetuates the gender gap. Q J Econ. 2010; 125(3):1101-1144.

Catsambis S. The path to math: Gender and racial-ethnic differences in mathematics participation from middle school to high school. Sociol of Educ. 1994; 67(3):199-215.

Cech E, Rubineau B, Silbey S, Seron C. Professional role confidence and gendered persistence in engineering. Am Sociol Rev. 2011; 76:641-66.

Ceci SJ, Williams WM. Sex differences in math-intensive fields. Current Dir in Psych Sci. 2010; 19:275-279.

Ceci SJ, Williams WM. Understanding current causes of women's underrepresentation in science. Proc Natl Acad Sci. 2011; 108:3157-3162. [PubMed: 21300892]

Ceci SJ, Williams WM, Barnett SM. Women's underrepresentation in science: sociocultural and biological considerations. Psych Bulletin. 2009; 135(2):218-261. 
Chang MJ, Sharkness J, Hurtado S, Newman CB. What matters in college for retaining aspiring scientists and engineers from underrepresented racial groups. J Res in Sci Teaching. 2014; 51(5): $555-580$.

Chang MJ, Eagan MK, Lin MH, Hurtado S. Considering the impact of racial stigmas and science identity: Persistence among biomedical and behavioral science aspirants. J of Higher Educ. 2011; 82(5):564-596. [PubMed: 23226874]

Chang MJ, Cerna O, Han J, Saenz V. The contradictory roles of institutional status in retaining underrepresented minorities in biomedical and behavioral science majors. Rev Higher Educ. 2008; 31(4):433-464.

Charles M, Bradley K. Equal but separate? A cross-national study of sex segregation in higher education. Am Sociol Rev. 2002; 67:573-599.

Charles, M.; Bradley, K. A matter of degrees: female underrepresentation in computer science programs cross-nationally. In: McGrath, J.; Aspray, B., editors. Women and Information Technology: Research on the Reasons for Underrepresentation. Cambridge, MA: MIT Press; 2006. p. 183-203.

Charles M, Bradley K. Indulging our gendered selves? Sex segregation by field of study in 44 countries. Am J Sociol. 2009; 114:924-976. [PubMed: 19824299]

Charles M, Harr B, Cech E, Hendley A. Who likes math where? Gender differences in eighth-graders' attitudes around the world. Internatl Stud in Sociol Educ. 2014; 24:85-112.

Chen, X. Students Who Study Science, Technology, Engineering, and Mathematics (STEM) in Postsecondary Education. Washington, DC: Natl. Center for Educ. Statistics; 2009.

Chen, X.; Soldner, M. STEM Attrition: College Students' Paths Into and Out of STEM Field. Washington, DC: Natl. Center for Educ. Statistics; 2014.

Cheryan S, Plaut VC, Davies PG, Steele CM. Ambient belonging: how stereotypical cues impact gender participation in computer science. J Person Soc Psychol. 2009; 97:1045-1060.

Cheryan S, Oliver J, Siy MV, Drury BJ, Kim S. Do female and male role models who embody STEM stereotypes hinder women's anticipated success in STEM? Soc and Person Sci. 2011; 2:656-664.

Chipman, SF. Research on the women and mathematics issue: a personal case history. In: Gallagher, AM.; Kaufman, JC., editors. Gender Differences in Mathematics. New York: Cambridge Univ. Press; 2005. p. 1-24.

Clotfelter CT, Ladd HF, Vigdor J. Who teaches whom? Race and the distribution of novice teachers. Econ of Educ Rev. 2005; 24(4):377-392.

Cogan LS, Schmidt WH. Culture shock: Eighth-grade mathematics from an international perspective. Educ Res and Eval. 2002; 8:13-39.

Cole D, Espinoza A. Examining the academic success of Latino students in science technology engineering and mathematics (STEM) majors. J of Coll Student Dev. 2008; 49:285-300.

Coleman, JS. Equality of Educational Opportunity. Washington, DC: Office of Educ., US Dept. of Health, Educ., and Welfare; 1968.

Coleman JS. Social capital in the creation of human capital. Am J Sociol. 1988; 94:S95-S120.

Condron DJ, Roscigno VJ. Disparities within: unequal spending and achievement in an urban school district. Soc of Educ. 2003; 76:18-36.

Correll SJ. Gender and the career choice process: the role of biased self-assessments. Am J Sociol. 2001; 106:1691-730.

Correll SJ. Constraints into preferences: gender, status, and emerging career aspirations. Am Sociol Rev. 2004; 69:93-113.

Crosnoe R. Low-income students and the socioeconomic composition of public high schools. Am Sociol Rev. 2009; 74:709-30. [PubMed: 21546987]

Croson R, Gneezy U. Gender differences in preferences. J Econ Lit. 2009; 47:1-27.

Cunha F, Heckman J. The economics and psychology of inequality and human development. J European Econ Assoc. 2009; 7:320-364. [PubMed: 20209045]

Cvencek D, Meltzoff AN, Greenwald AG. Math-gender stereotypes in elementary school children. Child Development. 2011; 82(3):766-779. [PubMed: 21410915] 
Dabney KP, Devasmita C, Tai RH. The association of family influence and initial interest in science. Sci Educ. 2013; 97(3):395-409.

Darling-Hammond, L. Teacher Quality and Student Achievement: A Review of State Policy Evidence. Seattle: Center for the Study of Teaching and Policy, Univ of Washington Seattle; 1999.

Deary IJ, Strand S, Smith P, Fernandes C. Intelligence and educational achievement. Intelligence. 2007; 35:13-21.

DeWitt J, Archer L, Osborne J, Dillon J, Willis B, Wong B. High aspirations but low progression: the science aspirations-careers paradox amongst minority ethnic students. Int J of Sci and Math Educ. 2011; 9(2):243-271.

Dika SL, Singh K. Applications of social capital in educational literature: a critical synthesis. Rev Educ Res. 2002; 72:31-60.

DiPrete, TA.; Buchmann, C. The Rise of Women: The Growing Gender Gap in Education and What It Means for American Schools. New York: Russell Sage Foundation; 2013.

DiPrete TA, Jennings JL. Social and behavioral skills and the gender gap in early educational achievement. Soc Sci Res. 2012; 41(1):1-15. [PubMed: 23017693]

Downey DB. When bigger is not better: family size, parental resources, and children's educational performance. Am Sociol Rev. 1995; 60(5):746-61.

Downey DB. Black/white differences in school performance: the oppositional culture explanation. Annu Rev Sociol. 2008; 34:107-26.

Downey DB, Von Hippel PT, Broh BA. Are schools the great equalizer? Cognitive inequality during the summer months and the school year. Am Sociol Rev. 2004; 69:613-35.

Duckworth AL, Seligman ME. Self-discipline outdoes IQ in predicting academic performance of adolescents. Psychol Sci. 2005; 16:939-44. [PubMed: 16313657]

Duncan GJ, Brooks-Gunn J, Klebanov PK. Economic deprivation and early childhood development. Child Dev. 1994; 65:296-318. [PubMed: 7516849]

Eccles, Jacquelynne S. Gendered educational and occupational choices: applying the Eccles et al model of achievement-related choices. Int J Behav Dev. 2011a; 35:195-201.

Eccles, Jacquelynne S. Understanding women's achievement choices: looking back and looking forward. Psychol Women Q. 2011b; 35:510-516.

Ellison G, Swanson A. The gender gap in secondary school mathematics at high achievement levels: evidence from the American mathematics competitions. J Econ Perspectives. 2010; 24:109-128.

Else-Quest NM, Hyde JS, Linn MC. Cross-national patterns of gender differences in mathematics: a meta-analysis. Psychol Bulletin. 2010; 136:103-127.

England P, Allison P, Li S, Mark N, Thompson J, Budig MJ, Sun H. Why are some academic fields tipping toward female? The sex composition of U.S fields of doctoral degree receipt, 1971-2002. Sociol Educ. 2007; 80:23-42.

England P, Li S. Desegregation stalled: the changing gender composition of college majors, 19712002. Gender \& Society. 2006; 20:657-677.

Fang Z, Grant LW, Xu X, Stronge JH, Ward TJ. An international comparison investigating the relationship between national culture and student achievement. Educ Assessment, Eval and Accountability. 2013; 25:1-19.

Farkas G. Cognitive skills and noncognitive traits and behaviors in stratification processes. Annu Rev of Sociol. 2003; 29:541-62.

Fischer, CS.; Hout, M.; Sánchez, M.; Jankowski, SR.; Lucas, AS.; Vos, K. Inequality by Design: Cracking the Bell Curve Myth. Princeton, NJ: Princeton Univ. Press; 1996.

Fischer, CS.; Hout, M. Century of Difference: How America Changed in the Last One Hundred Years. New York: Russell Sage Foundation; 2006.

Fredricks JA, Eccles JS. Children's competence and value beliefs from childhood through adolescence: growth trajectories in two male-sex-typed domains. Develop Psychol. 2002; 38:519_ 533.

Frome PM, Alfeld CJ, Eccles JS, Barber BL. Why don't they want a male-dominated job? An investigation of young women who changed their occupational aspirations. Educ Resand Evaluation. 2006; 12:359-372. 
Frome, PM.; Archer, L.; Eccles, JS.; Barber, BL. Is the desire for a family-flexible job keeping young women out of male-dominated occupations?. In: Watt, HMG.; Eccles, JS., editors. Gender and occupational Outcomes: Longitudinal Assessments of Individual, Social, and Cultural Influences. Washington, DC: Am. Psychol. Association; 2008. p. 195-214.

Fryer RG, Levitt SD. Understanding the black-white test score gap in the first two years of school. Rev Econ and Statistics. 2004; 86:447-64.

Fuchs T, Wößmann L. What accounts for international differences in student performance? A reexamination using PISA data. Empirical Econ. 2007; 32:433-62.

Gallagher, AM.; Levin, J.; Chalan, C. Cognitive patterns of gender differences on mathematics admission tests (ETS Research Report 02-19). Educational Testing Service; Princeton, NJ: 2002.

Gamoran A, Mare RD. Secondary school tracking and educational inequality: compensation, reinforcement, or neutrality? Am J Sociol. 1989; 94(5):1146-83.

Gerber TP, Cheung SY. Horizontal stratification in postsecondary education: forms, explanations, and implications. Ann Rev of Sociol. 2008; 34:299-318.

Gneezy U, Niederle M, Rustichini A. Performance in competitive environments: gender differences. Q J Econ. 2003; 118:1049-1074.

Gneezy U, Rustichini A. Gender and competition at a young age. Am Econ Rev. 2004; 94:377-381.

Goldin, CD.; Katz, LF. The Race between Education and Technology. Cambridge, MA: The Belknap Press of Harvard Univ. Press; 2008.

Gonzalez, HB.; Kuenzi, JJ. Science, Technology, Engineering, and Mathematics (STEM) Education: A Primer. 2012. Congressional Research Service 7-5700http://www.fas.org/sgp/crs/misc/ R42642.pdf

Graham MJ, Byars-Winston A, Hunter A-B, Handelsman J. Increasing persistence of college students in STEM. Sci. 2013; 341:1455-56.

Grandy J. Persistence in science of high-ability minority students: results of a longitudinal study. $\mathbf{J}$ Higher Educ. 1998; 69(6):589-620.

Greenman E, Bodovski K, Reed K. Neighborhood characteristics, parental practices and children's math achievement in elementary school. Soc Sci Res. 2011; 40:1434-44. [PubMed: 25125713]

Grodsky E, Warren JR, Felts E. Testing and social stratification in American education. Ann Rev Sociol. 2008; 34:385-404.

Greenwald R, Hedges LV, Laine RD. The effect of school resources on student achievement. Rev of Educ Res. 1996; 66:361-96.

Guiso L, Monte F, Sapienza P, Zingales L. Culture, gender, and math. Science. 2008; 320:1164-1165. [PubMed: 18511674]

Hallinan MT. Equality of educational opportunity. Ann Rev Sociol. 1988; 14:249-268.

Halpern DF. Sex differences in achievement scores: can we design assessments that are fair, meaningful, and valid for girls and boys? Issues in Educ. 2002; 8:2.

Halpern DF, Benbow CP, Geary DC, Gur RC, Hyde JS, Gernsbacher MA. The science of sex differences in science and mathematics. Psychol Sci in the Public Interest. 2007; 8:1-51.

Hanushek EA. Expenditures, efficiency, and equity in education: the federal government's role. Am Econ Rev. 1989; 79(2):F46-F51.

Hanushek, EA.; Peterson, PE.; Woessman, L. US Math Performance in Global Perspective: How Well Does Each State Do at Producing High-Achieving Students?. Harvard Univ; 2010. PEPG Report No.: 10-19

Harackiewicz JM, Rozek CR, Hulleman CS, Hyde JS. Helping parents to motivate adolescents in mathematics and science: An experimental test of a utility-value intervention. Psych Sci. 2012; 40:1-8.

Harding DJ. Counterfactual models of neighborhood effects: the effect of neighborhood poverty on dropping out and teenage pregnancy. Am J Sociol. 2003; 109:676-719.

Hattie, J. Visible Learning: A Synthesis of Over 800 Meta-Analyses Relating to Achievement. New York: Routledge; 2008.

Hauser RM, Tsai S-L, Sewell WH. A model of stratification with response error in social and psychological variables. Sociol Educ. 1983; 56:20-46. 
Heckman JJ, Pinto R, Savelyev PA. Understanding the mechanisms through which an influential early childhood program boosted adult outcomes. Am Econ Rev. 2013; 103(6):2052-86. [PubMed: 24634518]

Hedges LV, Laine RD, Greenwald R. An exchange: Part I: Does money matter? A meta-analysis of studies of the effects of differential school inputs on student outcomes. Educ Res. 1994; 23:5-14.

Hedges LV, Nowell A. Sex differences in mental test scores, variability, and numbers of high-scoring individuals. Sci. 1995; 269:41-45.

Hedges LV, Nowell A. Changes in the Black-White gap in achievement test scores. Sociol Educ. 1999; 72(2):111-35.

Herbert J, Stipek D. The emergence of gender differences in children's perceptions of their academic competence. J Applied Dev Psychol. 2005; 26:276-295.

Herrnstein, RJ.; Murray, C. The Bell Curve: Intelligence and Class Structure in American Life. New York: Free Press; 1994.

Hill HC, Rowan B, Ball DL. Effects of teachers' mathematical knowledge for teaching on student achievement. Am Educ Res J. 2005; 42:371-406.

Hill NE, Tyson DF. Parental involvement in middle school: A meta-analytic assessment of the strategies that promote achievement. Dev Psychol. 2009; 45:740-63. [PubMed: 19413429]

Honey, M.; Pearson, G.; Schweingruber, H., editors. STEM Integration in K-12 Education: Status, Prospects, and an Agenda for Research. National Academies Press; 2014.

Hsin A, Xie Y. Explaining Asian Americans' academic advantage over whites. Proc Natl Acad Sci. 2014; 111(23):8416-8421. [PubMed: 24799702]

Hurtado S. The campus racial climate: Contexts of conflict. J of Higher Educ. 1992; 35(1):539-569.

Hurtado S, Carter DF. Effects of college transition and perceptions of the campus racial climate on Latino college students' sense of belonging. Sociol Educ. 1997; 70(4):324-45.

Hyde JS. The gender similarities hypothesis. Am Psychol. 2005; 60:581-592. [PubMed: 16173891]

Hyde JS, Fennema E, Lamon SJ. Gender differences in mathematics performance: a meta-analysis. Psychol Bull. 1990a; 107:139-155. [PubMed: 2138794]

Hyde JS, Lindberg SM, Linn MC, Williams CC. Gender similarities characterize math performance. Sci. 2008; 321:494-495.

Hyde JS, Mertz JE. Gender, culture, and mathematics performance. Proc Natl Acad Sci. 2009; 106:8801-8807. [PubMed: 19487665]

Hyde JS, Feenema E, Ryan M, Frost LA, Hopp C. Gender comparisons of mathematics attitudes and affect: a meta-analysis. Psychol of Women Q. 1990b; 14:299-324.

Jacobs JE, Chhin CS, Bleeker MM. Enduring links: parents' expectations and their young adult children's gender-typed occupational choices. Educ Res and Eval. 2006; 12:395-407.

Jacobs, JE.; Davis-Kean, P.; Bleeker, MM.; Eccles, JS.; Malanchuk, O. "I can, but I don't want to": the impact of parents, interests, and activities on gender differences in math. In: Gallagher, AM.; Kaufman, JC., editors. Gender Differences in Mathematics. New York: Cambridge Univ. Press; 2005. p. 73-98.

Jæger MM. Does cultural capital really affect academic achievement? New evidence from combined sibling and panel data. Sociol of Educ. 2011; 84:281-98.

Jæger MM. The extended family and children's educational success. Am Sociol Rev. 2012; 77(6):903922.

Jencks, C.; Phillips, M. The Black White test score gap. Washington D.C: Brookings Institution Press; 1998.

Jencks, C.; Bartlett, S.; Corcoran, M.; Crouse, J.; Eaglesfield, D.; Jackson, G.; McClelland, K.; Mueser, P.; Olneck, M.; Shwartz, J.; Ward, S.; Williams, J. Who Gets Ahead?: The Determinants of Economic Success in America. Vol. 199. New York: Basic Books; 1979.

Jeynes WH. A meta-analysis of the relation of parental involvement to urban elementary school student academic achievement. Urban Educ. 2005; 40:237-69.

Kao G, Thompson J. Racial and ethnic stratification in educational achievement and attainment. Ann Rev of Sociol. 2003; 29:417-42. 
Kaushal, N.; Magnuson, K.; Waldfogel, J. How is family income related to investments in children's learning. In: Duncan, GJ.; Murnane, RJ., editors. Wither Opportunity? Rising Inequality, Schools, and Children's Life Chances. New York: Russell Sage Foundation; 2011. p. 187-205.

Kelly S. The black-white gap in mathematics course taking. Sociol Educ. 2009; 82:47-69.

Kenney-Benson GA, Pomerantz EM, Ryan AM, Patrick H. Sex differences in math performance: the role of children's approach to schoolwork. Dev Psychol. 2006; 42:11-26. [PubMed: 16420115]

Kiefer AK, Sekaquaptewa D. Implicit stereotypes, gender identification, and math-related outcomes: prospective study of female college students. Psych Sci. 2007; 18:13-18.

Killewald A, Xie Y. American science education in its global and historical contexts. Bridge. 2013; 43:15-23.

Kim HS. Consequences of parental divorce for child development. Am Sociol Rev. 2011; 76:487-511.

Knobloch-Westerwick S, Glynn CJ, Huge M. The matilda effect in science communication: an experiment on gender bias in publication quality perceptions and collaboration interest. Sci Communication. 2013; 35:603-625.

Koenig KA, Frey MC, Detterman DK. ACT and general cognitive ability. Intelligence. 2008; 36:15360.

Koput, KW.; Gutek, BA. Gender Stratification in the IT Industry: Sex, Status and Social Capital. Northampton, MA: Edward Elgar; 2010.

Krueger AB. Economic considerations and class size. Econ J. 2003; 113(485):F34-F63.

Langen AV, Dekkers H. Cross-national differences in participating in tertiary science, technology, engineering and mathematics education. Comp Educ. 2005; 41:329-50.

Lareau, A. Unequal Childhoods: Class, Race, and Family Life, with an Update a Decade Later. Berkeley: Univ. of California Press; 2011.

Lauen DL, Gaddis SM. Exposure to classroom poverty and test score achievement: contextual effects or selection? Am J Sociol. 2013; 118:943-79.

Lavy V, Sand E. On the origins of gender human capital gaps: Short and long term consequences of teachers' stereotypical biases. National Bureau of Economic Research Working Paper Series. 2015; (20909)

Legewie J, DiPrete TA. The High School Environment and the Gender Gap in Science and Engineering. Sociol Educ. 2014a; 87:259-280.

Legewie J, DiPrete TA. Pathways to science and engineering bachelor's degrees for men and women. Sociol Sci. 2014b; 1:41-48. [PubMed: 25089284]

Leslie S, Cimpian A, Meyer M, Freeland W. Expectations of brilliance underlie gender distributions across academic disciplines. Science. 2015; 347:262-265. [PubMed: 25593183]

Lindberg SM, Hyde JS, Petersen JL. New trends in gender and mathematics performance: a metaanalysis. Psychol Bull. 2010; 136:1123-1135. [PubMed: 21038941]

Linn MC, Petersen AC. Emergence and characterization of sex differences in spatial ability: a metaanalysis. Child Dev. 1985; 56:1479-1498. [PubMed: 4075870]

Logan JR, Minca E, Adar S. The geography of inequality: Why separate means unequal in American public schools. Soc of Educ. 2012; 85(3):287-301.

Logel C, Walton GM, Spencer SJ, Iserman EC, von Hippel W, Bell AE. Interacting with sexist men triggers social identity threat among female engineers. J Person Soc Psychol. 2009; 96:10891103.

Lubinski DS, Benbow CP. Study of mathematically precocious youth after 35 years: Uncovering antecedents for the development of math-science expertise. Perspectives on Pysch Sci. 2006; 1(4):316-345.

Lynn R. Racial and ethnic differences in intelligence in the United States on the Differential Ability Scale. Personality and Indiv Differences. 1996; 20(2):271-273.

Lynn R, Mikk J. National IQs predict educational attainment in math, reading and science across 56 nations. Intelligence. 2009; 37(3):305-310.

Ma Y. Family socioeconomic status, parental involvement, and college major choices: gender, race/ ethnic, and nativity patterns. Sociol Perspectives. 2009; 52:211-34. 
Ma Y. Gender differences in the paths leading to a STEM baccalaureate. Soc Sci Q. 2011; 92:11691190.

Maltese AV, Tai RH. Eyeballs in the fridge: sources of early interest in science. Int J of Sci Educ. 2010; 32:669-85.

Maltese AV, Tai RH. Pipeline persistence: examining the association of educational experiences with earned degrees in STEM among US students. Sci Educ. 2011; 95:877-907.

Mann A, DiPrete TA. Trends in gender segregation in the choice of science and engineering majors. Soc Sci Res. 2013; 42:1519-1541. [PubMed: 24090849]

Maple SA, Stage FK. Influences on the choice of math/science major by gender and ethnicity. Am Educ Res J. 1991; 28:37-60.

Marks, GN. Education, social background and cognitive ability: the decline of the social. New York: Taylor \& Francis; 2013.

Massey, DS. American Apartheid: Segregation and the Making of the Underclass. Harvard Univ. Press; 1993.

Mau WC. Factors that influence persistence in science and engineering career aspirations. Career Dev Q. 2003; 51:234-43.

Mayer, SE. What Money Can't Buy: Family Income and Children's Life Chances. Cambridge: Harvard Univ. Press; 1997.

McLanahan, S.; Sandefur, GD. Growing up with a Single Parent: What Hurts, what Helps. Cambridge: Harvard Univ. Press; 1994.

McLoyd VC. Socioeconomic disadvantage and child development. Am Psychologist. 1998; 53:185.

Merton, RK. The normative structure of science. In: Merton, R., editor. The Sociology of Science: Theoretical and Empirical Investigations. Chicago: Univ. of Chicago Press; 1942. p. 267-78.Reprinted (1973)

Miller PH, Blessing JS, Schwartz S. Gender differences in high-school students' views about science. Int JSci Educ. 2006; 28:363-381.

Miller JD, Kimmel LG. Pathways to a STEMM profession. Peabody J Educ. 2012; 87:26-45.

Miller DI, Wai J. The bachelor's to PhD STEM pipeline no longer leaks more women than men: A 30Year analysis. Frontiers in Psychology. 2015; 6:37. [PubMed: 25741293]

Mincer, J. Schooling, Experience, and Earnings. New York: Columbia Univ. Press; 1974.

Morgan SL, Gelbgiser D, Weeden KA. Feeding the pipeline: gender, occupational plans, and college major selection. Soc Sci Res. 2013; 42:989-1005. [PubMed: 23721669]

Moss-Racusin CA, Dovidio JF, Brescoll VL, Graham MJ, Handelsman J. Science faculty's subtle gender biases favor male students. Proc Natl Acad Sci. 2012; 109(41):16474-16479. [PubMed: 22988126]

Mulligan, GM.; Hastedt, S.; McCarroll, JC. First-time Kindergartners in 2010-11: First Findings from the Kindergarten Rounds of the Early Childhood Longitudinal Study, Kindergarten Class of 2010-11 (ECLS-K:2011). Washington, DC: Nat. Center for Educ. Statistics.; 2012.

Murphy MC, Steele CM, Gross J. Signaling threat: how situational cues affect women in math, science, and engineering settings. Psychol Science. 2007; 18:879-885.

Museus SD, Palmer RT, Davis RJ, Maramba DC. Special issue: racial and ethnic minority students' success in STEM education. ASHE Higher Educ Report. 2011; 36:1-140.

National Academy of Science (NAS), National Academy of Engineering (NAE), and Institute of Medicine (IM). Rising above the Gathering Storm: Energizing and Employing America for a Brighter Economic Future. Washington, DC: National Academies Press; 2007.

National Center for Education Statistics (NCES). Pursuing Excellence: Comparisons of International Eighth-Grade Mathematics and Science Achievement from a US Perspective, 1995 and 1999. Washington, DC: US Govt Printing Office; 2000.

NCES. Teaching Science in Five Countries: Results From the TIMSS 1999 Video Study. Washington DC: US Govt Printing Office; 2006.

NCES. Status of Education in Rural American. Washington DC: Nat. Center for Educ. Statistics; 2007. 
NCES. Highlights From TIMSS 2011: Mathematics and Science Achievement of US Fourth- and Eighth-Grade Students in an International Context. Washington, DC: Nat. Center for Educ. Statistics; 2011.

NCES. Higher Education: Gaps in Access and Persistence Study. Washington, DC: Nat. Center for Educ. Statistics; 2012.

NCES. Performance of US 15-Year-Old Students in Mathematics, Science, and Reading Literacy in an International Context: First Look at PISA 2012. Washington, DC: Nat. Center for Educ. Statistics; 2013a.

NCES. The Nation's Report Card: Trends in Academic Progress 2012. Washington, DC: Nat. Center for Educ. Statistics; 2013b.

NCES. Characteristics of Public and Private Elementary and Secondary School Teachers in the United States: Results from the 2011-12 Schools and Staffing Survey. Washington, DC: Nat. Center for Educ. Statistics; 2013c.

National Science Board (NSB). Science and Engineering Indicators 2012. Arlington, VA: Nat. Center for Sci. and Engineering Statistics; 2012.

NSB. Science and Engineering Indicators 2014. Arlington, VA: Nat. Center for Sci. and Engineering Statistics; 2014.

Neal, D. Why Has Black-White Skill Convergence Stopped?. Univ. of Chicago; 2005. Work. Pap

Next Generation Science Standards (NGSS). 2015. http://www.nextgenscience.org/

Newcome NS. Picture this: increasing math and science learning by improving spatial thinking. Am Educator. 2010; 34(2):29.

Nguyen H-HD, Ryan AM. Does stereotype threat affect test performance of minorities and women? A meta-analysis of experimental evidence. J Applied Psychol. 2008; 93:1314-1334. [PubMed: 19025250]

Niederle M, Vesterlund L. Do women shy away from competition? Do men compete too much? Q J Econ. 2007; 122:1067-1101.

Niederle M, Vesterlund L. Explaining the gender gap in math test scores: the roles of competition. J Econ Perspectives. 2010; 24:129-144.

Nisbett, RE. Intelligence and How to Get it: Why Schools and Cultures Count. New York: WW Norton \& Company; 2009.

Nord, C.; Roey, S.; Perkins, R.; Lyons, M.; Lemanski, N.; Brown, J.; Schuknecht, J. The Nation's Report Card: America's High School Graduates. Washington, DC: U.S. Govt. Printing Office; 2011. NCES Work. Pap. 2011-462http://nces.ed.gov/nationsreportcard/pdf/studies/2011462.pdf

Nosek BA, Smyth FL, Sriram N, Lindner NM, Devos T, Ayala A, Bar-Anan Y, Bergh R, Cai H, Gonsalkorale K, Kesebir S, Maliszewski N, Neto F, Olli E, Park J, Schnabel K, Shiomura K, Tulbure BT, Wiers RW, Somogyi M, Akrami N, Ekehammar B, Vianello M, Banaji MR, Greenwald AG. National differences in gender-science stereotypes predict national sex differences in science and math achievement. Proc Natl Acad Sci USA. 2009; 106:10593-7. [PubMed: 19549876]

Nosek BA, Banaji MR, Greenwald AG. Math $=$ male, $m e=$ female, therefore math $\neq$ me. J Personal Soc Psychol. 2002; 83:44-59.

Oakes, J. Multiplying Inequalities: The Effects of Race, Social Class, and Tracking on Opportunities to Learn Mathematics and Science. Santa Monica: The RAND Corporation; 1990.

Oakes J, Saunders M. Education's most basic tools: Access to textbooks and instructional materials in California's public schools. The Teachers Col Record. 2004; 106(10):1967-1988.

Organization for Economic Co-operation and Development (OECD). PISA 2009 Results: Overcoming Social Background - Equity in Learning Opportunities and Outcomes (Volume II). Paris: OECD Publishing; 2010.

Osborne J, Simon S, Collins S. Attitudes towards science: a review of the literature and its implications. Int J of Sci Educ. 2003; 25(9):1049-1079.

Pavitt K. National policies for technical change: where are the increasing returns to economic research? Proc Natl Acad Sci USA. 1996; 93:12693-12700. [PubMed: 8917481] 
Penner AM. Gender differences in extreme mathematical achievement: an international perspective on biological and social factors. Am J Sociol. 2008; 114:S138-S170. [PubMed: 19569403]

Penner AM, Paret M. Gender differences in mathematics achievement: Exploring the early grades and the extremes. Soc Sci Res. 2008; 37:239-253.

Perez T, Cromley JG, Kaplan Avi. The role of identity development, values, and costs in college STEM retention. J of Educ Psych. 2014; 106(1):315-329.

Perez-Felkner L, McDonald S-K, Schneider B, Grogan E. Female and male adolescents' subjective orientations to mathematics and the influence of those orientations on postsecondary majors. Dev Psychol. 2012; 48:1658-1673. [PubMed: 22390658]

Plomin R, Owen MJ, McGuffin P. The genetic basis of complex human behaviors. Science 17. 1994; 264(5166):1733-1739.

Price, DJ. Little Science, Big Science- and Beyond. New York: Columbia Univ. Press; 1986.

Raftery A, Hout M. Maximally maintained inequality - expansion, reform, and opportunity in Irish education, 1921-75. Sociol Educ. 1993; 66:41-62.

Raudenbush S, Bryk AS. A hierarchical model for studying school effects. Sociol Educ. 1986; 59:117.

Reardon, S. Thirteen ways of looking at the black-white test score gap. Stanford Institute for Res. on Educ. Policy and Practice; Stanford, CA: 2008. Work. Pap. 8

Reardon, SF. The widening academic achievement gap between the rich and the poor: new evidence and possible explanations. In: Duncan, GJ.; Murnane, R., editors. Whither Opportunity? Rising Inequality, Schools, and Children's Life Chances. New York: Russell Sage Found; 2011. p. 91-116.

Reardon SF, Bischoff K. Income inequality and income segregation. American Journal of Sociology. 2011; 116:1092-1153.

Reardon, SF.; Baker, R.; Klasik, D. Race, income, and enrollment patterns in highly selective colleges, 1982-2004. Stanford Institute for Res. on Educ. Policy and Practice; Stanford, CA: 2012.

Reilly D, Neumann DL. Gender-role differences in spatial ability: a meta-analytic review. Sex Roles. 2013:1-15.

Reuben E, Sapienza P, Zingales L. How stereotypes impair women's careers in science. Proc Natl Acad Sci USA. 2014; 111(12):4403-4408. [PubMed: 24616490]

Ridgeway CL. Why status matters for inequality. Am Sociol Rev. 2014; 79:1-16.

Ridgeway CL, Correll SJ. Unpacking the gender system: a theoretical perspective on gender beliefs and social relations. Gender \& Society. 2004; 18:510-531.

Riegle-Crumb C, Farkas G, Muller C. The role of gender and friendship in advanced course taking. Soc of Educ. 2006; 79(3):206-228.

Riegle-Crumb C, Grodsky E. Racial-ethnic differences at the intersection of math course-taking and achievement. Soc of Educ. 2010; 83(3):248-270.

Riegle-Crumb C, Humphries M. Exploring bias in math teachers' perceptions of students' ability by gender and race/ethnicity. Gender \& Society. 2012; 26:290-322.

Riegle-Crumb C, King B. Questioning a white male advantage in STEM: Examining disparities in college major by gender and race/ethnicity. Educ Researcher. 2010; 39:656-64.

Riegle-Crumb C, King B, Grodsky E, Muller C. The more things change, the more they stay the same? Prior achievement fails to explain gender inequality in entry into STEM college majors over time. Am Educ Res J. 2012; 49:1048-1073.

Riegle-Crumb C, Moore C, Ramos-Wada A. Who wants to have a career in science or math? exploring adolescents' future aspirations by gender and race/ethnicity. Sci Educ. 2011; 95:458-476.

Robertson KF, Smeets S, Lubinski D, Benbow CP. Beyond the threshold hypothesis: even among the gifted and top math/science graduate students, cognitive abilities, vocational interests, and lifestyle preferences matter for career choice, performance, and persistence. Current Directions in Psychol Sci. 2010; 19:346-351.

Rockoff JE. The impact of individual teachers on student achievement: evidence from panel data. Am Econ Rev. 2004; 94:247-52. 
Rohde TE, Thompson LA. Predicting academic achievement with cognitive ability. Intelligence. 2007; 35:83-92.

Roksa J, Potter D. Parenting and academic achievement: intergenerational transmission of educational advantage. Sociol of Educ. 2011; 84:299-321.

Rothwell, J. The Hidden STEM Economy. Brookings Institute; 2013. http://www.brookings.edu/ research/reports/2013/06/10-stem-economy-rothwell

Sadler PM, Sonnert G, Coyle HP, Cook-Smith N, Miller JL. The influence of teachers' knowledge on student learning in middle school physical science classrooms. Am Educational Res J. 2013; 50(5):1020-49.

Sadler PM, Sonnert G, Hazari Z, Tai R. Stability and volatility of STEM career interest in high school: a gender study. Sci Educ. 2012; 96:411-427.

Sampson RJ, Sharkey P, Raudenbush SW. Durable effects of concentrated disadvantage on verbal ability among African-American children. Proc Natl Acad Sci USA. 2008; 105:845-52. [PubMed: 18093915]

Sastry N, Pebley AR. Family and neighborhood sources of socioeconomic inequality in children's achievement. Demography. 2010; 47:777-800. [PubMed: 20879688]

Schmidt FL. A theory of sex differences in technical aptitude and some supporting evidence. Perspect Psychol Sci. 2011; 6:560-573. [PubMed: 26168377]

Schmidt WH. At the precipice: the story of mathematics education in the United States. Peabody J Educ. 2012; 87:133-56.

Schneider B, Swanson CB, Riegle-Crumb C. Opportunities for learning: course sequences and positional advantages. Soc Psychol Educ. 1998; 2:25-53.

Sewell WH, Haller AO, Portes A. The educational and early occupational attainment process. Am Sociol Rev. 1969; 34:82-92.

Seymour, E.; Hewitt, NM. Talking about Leaving: Why Undergraduates Leave the Sciences. Colorado: Westview Press Boulder; 1997.

Sharkey P, Elwert F. The legacy of disadvantage: multigenerational neighborhood effects on cognitive ability. Am J Sociol. 2011; 116:1934-81. [PubMed: 21932471]

Sheltzer JM, Smith JC. Elite male faculty in the life sciences employ fewer women. Proc Natl Acad Sci. 2014; 111(28):10107-10112. [PubMed: 24982167]

Shepherd H. The cultural context of cognition: what the implicit association test tells us about how culture works. Sociol Forum. 2011; 26:121-143.

Shettle, C.; Roey, S.; Mordica, J.; Perkins, R.; Nord, C.; Teodorovick, J.; Brown, J.; Lyons, M.; Averett, C.; Kastberg, D. America's high school graduates: results from the 2005 NAEP high school transcript study. Washington DC: U.S. Department of Education; 2007.

Simpkins SD, Davis-Kean PE, Eccles JS. Math and science motivation: a longitudinal examination of the links between choices and beliefs. Dev Psych. 2006; 42(1):70-83.

Sjaastad J. Sources of Inspiration: the role of significant persons in young people's choice of science in higher education. Int J of Sci Educ. 2012; 34(10):1615-1636.

Sousa S, Park EJ, Armor DJ. Comparing effects of family and school factors on cross-national academic achievement using the 2009 and 2006 PISA Surveys. J of Comparative Policy Analysis: Res and Practice. 2012; 14:449-68.

Spelke E. Sex differences in intrinsic aptitude for mathematics and science? A critical review. Am Psychol. 2005; 60:950-958. [PubMed: 16366817]

Steele J, James JB, Barnett RC. Learning in a man's world: examining the perceptions of undergraduate women in male-dominated academic areas. Psychol Women Q. 2002; 26:46-50.

Steelman LC, Powell B, Werum R, Carter S. Reconsidering the effects of sibling configuration: recent advances and challenges. Ann Rev of Sociol. 2002; 28:243-27.

Stevenson HW, Stigler JW. The learning gap: why our schools are failing and what we can learn from Japanese and Chinese education. New York. 1992

Stout JG, Dasgupta N, Hunsinger M, McManus MA. STEMing the tide: using ingroup experts to inoculate women's self-concept in science, technology, engineering, and mathematics (STEM). J of Person Soc Psychol. 2011; 100:255-270. 
Su R, Rounds J, Armstrong PI. Men and things, women and people: a meta-analysis of sex differences in interests. Psychol Bull. 2009; 135:859-884. [PubMed: 19883140]

Tai RH, Liu CQ, Maltese AV, Fan X. Planning early for careers in science. Science. 2006; 312:114344. [PubMed: 16728620]

Tay L, Su R, Rounds J. People-things and data-ideas: bipolar dimensions? J Counseling Psychol. 2011; 5:424-440.

Tenenbaum HR, Ruck MD. Are teachers' expectations different for racial minority than for European American students? A meta-analysis. J Educ Psychol. 2007; 99:253.

Tinto, V. Leaving College: Rethinking the Causes and Cures of Student Attrition. Chicago: Univ. of Chicago Press; 1987.

Tsui M. Family income, home environment, parenting, and mathematics achievement of children in China and the United States. Educ and Urban Society. 2005; 37(3):336-355.

Turner SL, Steward JC, Lapan RT. Family factors associated with sixth-grade adolescents' math and science career interests. The Career Dev Q. 2004; 53:41-52.

Turney, K.; McLanahan, S. The academic consequences of early childhood problem behaviors. Center for Research on Child Wellbeing, Woodrow Wilson School of Public and International Affairs, Princeton Univ; Princeton, NJ: 2012. Work Pap No.1427

Tytler, R.; Osborne, J. Student attitudes and aspirations towards science. In: Fraser, BJ.; Tobin, K.; McRobbie, CJ., editors. Second International Handbook of Science Education. Netherlands: Springer; 2012. p. 597-625.

U.S. Census Bureau. Annual Estimates of the Resident Population by Sex, Age, Race, and Hispanic Origin for the United States and States: April 1, 2010 to July 1, 2013. 2014. http:// factfinder2.census.gov/faces/tableservices/jsf/pages/productview.xhtml?src=bkmk

Valian V. Interests, gender, and science. Perspect Psychol Sci. 2014; 9:225-230. [PubMed: 26173256]

Valla JM, Ceci SJ. Can sex differences in science be tied to the long reach of prenatal hormones? Brain organization theory, digit ratio (2D/4D), and sex differences in preferences and cognition. Perspect Psychol Sci. 2011; 6:134-146. [PubMed: 22164187]

Wai J, Cacchio M, Putallaz M, Makel MC. Sex differences in the right tail of cognitive abilities: a 30year examination. Intelligence. 2010; 38:412-423.

Wang M-T, Eccles JS, Kenny S. Not lack of ability but more choice: individual and gender differences in choice of careers in science, technology, engineering, and mathematics. Psychol Sci. 2013; 24:770-775. [PubMed: 23508740]

Wang X. Why students choose STEM majors motivation, high school learning, and postsecondary context of support. Am Educ Res J. 2013; 50(5):1081-1121.

Ware NC, Lee VE. Sex differences in choice of college science majors. Am Educ Res J. 1988; 25(4): 593-614.

Watt HMG. Development of adolescents' self-perceptions, values, and task perceptions according to gender and domain in 7th- through 11th-grade Australian students. Child Develop. 2004; 75:1556-1574. [PubMed: 15369531]

Watt HMG. The role of motivation in gendered educational and occupational trajectories related to maths. Educat Res and Eval. 2006; 12:305-322.

Wayne AJ, Youngs P. Teacher characteristics and student achievement gains: a review. Rev of Educ Res. 2003; 73:89-122.

Weinberger, CJ. Is the science and engineering workforce drawn from the far upper tail of the math ability distribution?. Institute for Social,Behavioral, and Economic Research and Department of Economics Univ. of California; Santa Barbara: 2005. Work Pap.http://www.econ.ucsb.edu/ $\sim$ weinberg/uppertail.pdf

Willis RJ, Rosen S. Education and self-selection. J Polit Econ. 1979; 87:S7-36.

Woolnough, BE. Effective Science Teaching Developing Science and Technology Education. United Kingdom: Open Univ; 1994.

Xie, Y. The Process of Becoming a Scientist. Department of Sociology the Univ. of WisconsinMadison; 1989. Unpublished dissertation 
Xie Y, Goyette K. Social mobility and the educational choices of Asian Americans. Soc Sci Res. 2003; 32:467-98.

Xie, Y.; Killewald, AA. Is American Science in Decline?. Cambridge: Harvard Univ. Press; 2012.

Xie, Y.; Shauman, KA. Women in Science: Career Processes and Outcomes. Cambridge, MA:

Harvard Univ. Press; 2003. 